\title{
HERITAGE VALUE FROM BELOW. A LOCAL COMMUNITY PERSPECTIVE ON CONSERVATION, PRESERVATION AND AUTHENTICITY IN SE SWEDEN
}

VALOR PATRIMONIAL VISTO DE BAIXO. UMA PERSPECTIVA COMUNITÁRIA SOBRE CONSERVAÇÃO, PRESERVAÇÃO E SUTENTICIDADE NA SUÉCIA

Como citar este artigo:

PAPMEHL-DUFAY, Ludvig. Heritage value from below: A local community perspective on conservation, preservation and authenticity in SE Sweden. Cadernos do Lepaarq, v. XVII, n.34, p. 58-73, Jul-Dez. 2020. 


\section{Heritage value from below. A local community perspective on conservation, preservation and authenticity in SE Sweden}

Ludvig Papmehl-Dufay ${ }^{\mathrm{a}}$

\begin{abstract}
:
This paper discusses how archaeological heritage can function as a focus of community identity in a rural setting, and what happens when an original monument is replaced by a copy. The case study presented deals with a visually striking ancient monument on the island of Öland, SE Sweden, that was accidentally broken in 2014 and later reconstructed. This case thus touches upon concepts such as authenticity, age value and aura of ancient objects and monuments, but also community engagement in local heritage and the ability of archaeology in adding value to existing sites and monuments. It is concluded that a dissonance often exists between the official assessment of heritage value, and values appreciated by the local community. In the latter, social value can be seen as connected to the concept of pastness, where a range of factors both material and immaterial combine to render a monument or a site its perceived significance.
\end{abstract}

\section{Keywords:}

Heritage values, pastness, local community, standing stone, phallos, ship-shaped stone setting, reconstruction, Albrunna, Öland, Sweden.

\section{Resumo:}

Este artigo discute como o patrimônio arqueológico pode funcionar como um foco de identidade comunitária em um ambiente rural, e o que acontece quando um monumento original é substituído por uma cópia. O estudo de caso apresentado trata de um monumento antigo visualmente impressionante na ilha de Öland, sudeste da Suécia, que foi quebrado acidentalmente em 2014 e posteriormente reconstruído. Este caso, portanto, aborda conceitos como autenticidade, valor de idade e aura de objetos e monumentos antigos, mas também o envolvimento da comunidade no patrimônio local e a capacidade da arqueologia em acrescentar valor aos monumentos locais e sítios existentes. É concluído que existe uma dissonância muitas vezes entre a avaliação oficial do valor patrimonial e os valores apreciados pela comunidade local. Neste último caso, o valor social pode ser visto como conectado ao conceito de passado, onde uma gama de fatores tanto materiais quanto imateriais se combinam para dar a um monumento ou local seu significado percebido.

\section{Palavras-chave:}

Valores patrimoniais, passado, comunidade local, megálito, fálus, momento megalítico em forma de navio, reconstrução, Albrunna, Öland, Suécia. 


\section{INTRODUCTION: ARCHAEOLOGICAL HERITAGE, VALUE AND AUTHENTICITY}

In the professional National heritage discourse in Sweden, ancient monuments and sites are protected by law (SFS 1988:950). The law defines what constitutes an ancient site or monument (Sw "fornlämning"), and prohibits anyone from moving, removing, excavate, cover or by other means damage an ancient site or monument. The protection of ancient remains in this way is generally motivated by a shared obligation to preserve them for future generations, even though this future is never defined (HÖGBERG et al., 2018). From a local community perspective, heritage value often rests on other premises, not necessarily in line with the official heritage discourse (MYDLAND e GRAHN, 2012). In recent decades, the social value of heritage especially in a local community perspective has been brought to the fore (see JONES, 2017). These values often connect to a sense of local identity, place attachment and belonging, in contrast to what is usually prioritized in the official rhetoric on heritage (AUSTRALIA ICOMOS Practice note 2013). As will be shown in the following, this potential dissonance has consequences for heritage management, especially when the values of local heritage are assessed and efforts are taken to meet local engagement in the protection and preservation of heritage.

Archaeological stone monuments typically have a special character of age, authenticity and authority surrounding them. But what exactly is it that renders them this value? In his influential work from 1903 on "The modern cult of monuments", Riegl characterized the "age value" of a monument as properties that "reveals the passage of a considerable period of time" (RIEGL, 1982). Walter Benjamin later described this unique property as the "aura" of a monument or an artefact, and defined this as "the essence of all that is transmissible from its beginning, ranging from its substantive duration to its testimony to the history which it has experienced" (BENJAMIN, 1968, quoted in JEFFREY, 2015). One of his points was that in reproducing an ancient work of art (or a monument, for that matter), its aura and thus its authenticity is lost (aa). In recent decades, the significance of "age value" as a defining characteristic of heritage value has been contested (e.g. HOLTORF \& SCHADLA-HALL, 1999; HOLTORF, 2017). Holtorf argued that age value can be reproduced and that it is not related to the actual age of an object or a monument, but to the perception of its pastness in a given context (HOLTORF, 2017). Hence, a well-made copy or an artificial ruin may possess as much pastness and evoke the same feelings as any "original" ancient artefact or monument. A brilliant example of this is the full-scale replica of the Chauvet cave in France. Here, huge efforts were made to replicate in minute detail the full experience of entering the original paleolithic rock art cave, resulting in an artificial rock art site full of "aura" and sense of authenticity (DUVAL et al. 2020). Focus in the replication was completely on the interior of the cave and its artistic expressions, however, and while an authentic experience of these aspects apparently was successfully recreated, the environmental surroundings of the cave and the cultural-historical context of paleolithic rock art was more or less neglected altogether (DUVAL et al., 2020:157). This last point emphasizes the fact that while a sense of pastness no doubt can be (re)created, replications and reconstructions always involve a certain degree of interpretation. 


\section{HERITAGE VALUE ON ÖLAND}

In areas with an abundance of standing stones and other prehistoric monuments, a character or "aura" of age, authenticity and uniqueness often strongly influences the way the landscape is perceived and appreciated today. An example of this is the island of Öland, located in the Baltic Sea outside the mainland coast of SE Sweden (PAPMEHL-DUFAY, 2006: 65ff) (fig. 1). Like its distant neighbor Gotland to the east, Öland consist of limestone providing an extremely flat landscape in sharp contrast to the mainland coast. Owing to its unique natural conditions, Öland has been a focus of interest for people of many disciplines and professions. Nowadays the island is a popular summer home for thousands of Swedish and foreign tourists and it has a substantial number of artists living there all year round, attracted by the fascinating and unique landscape. Ornithologists and birdwatchers come from far and near each year, and the unique flora and fauna of the Great Alvar is another source of attraction for both scholars and laymen. The southern third of the island was declared a World Heritage Site by UNESCO in year 2000, in recognition of its varied and wellpreserved historical agrarian landscape.

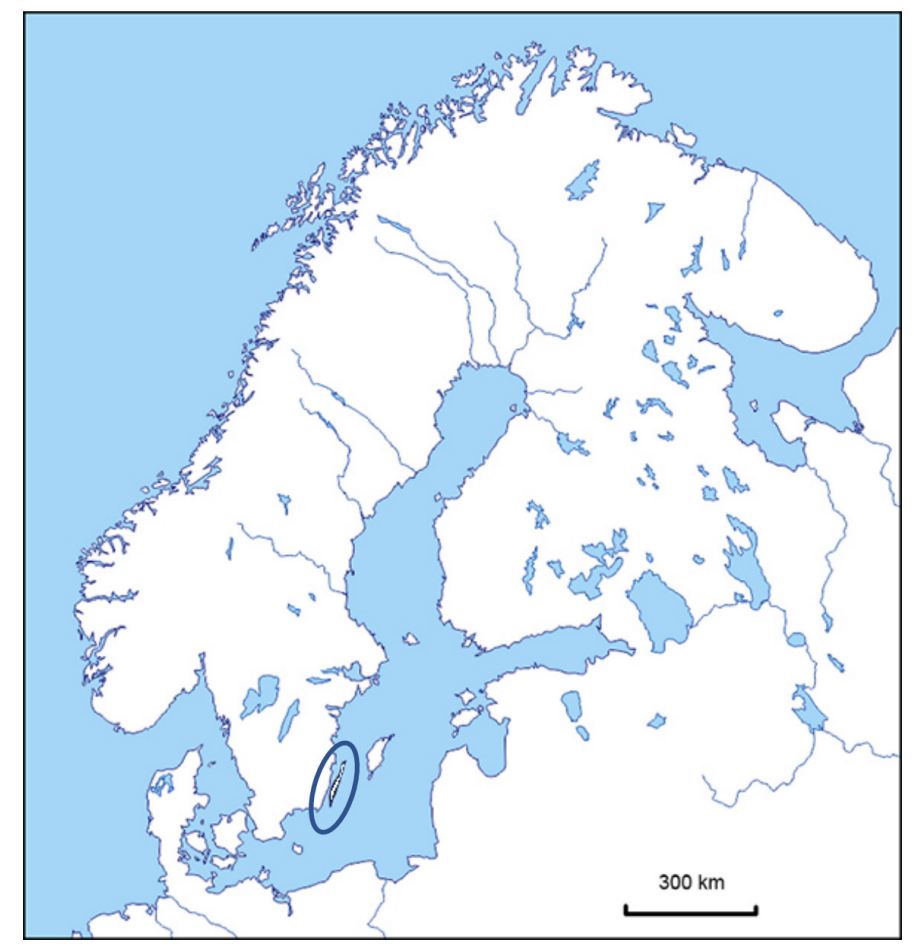

Figure 1. Map of Scandinavia, with the island of Öland indicated (circle).

With some 14000 recorded ancient sites and monuments and massive numbers of stray finds of prehistoric artefacts from all periods, Öland is the second most archaeologically productive region in Sweden, exceeded only by Gotland (HÄGGSTRÖM, 2003: 15). For visitors as well as residents, the past is highly present almost everywhere on the island in the form of visible archaeological remains such as ancient cemeteries, ring forts and settlements. Furthermore, the historical agrarian landscape with archaic villages, windmills and miles upon miles of old stone fences contribute to 
this historical "aura". However, the extent to which this value is appreciated varies greatly, and while some people may hold it as the reason for their choice of residence, other will probably refute it altogether. Still, in many areas around the island the visible ancient heritage plays an important role for local communities and the sense of a local identity.

\section{CASE STUDY: THE ALBRUNNA STONE}

This is the case in the village of Albrunna, a small rural community on SW Öland with around 50 permanent residents. The main road passes through the village, which offers a well-stocked nursery-garden, vegetable sales directly from the fields, and even a small private museum presenting the local history in photographs, artefacts and curiosities. Some of the villagers are farmers with many generations of family history connected to the village, while another portion has moved in from elsewhere during the last three or four decades.

At Albrunna, a particular ancient monument has caught the attention of travelers for centuries. For most of the $20^{\text {th }}$ century, the Albrunna stone was visible as a $1 \mathrm{~m}$ wide and $4 \mathrm{~m}$ high standing limestone slab located just south of the village, oriented $\mathrm{N}-\mathrm{E}$ and tilting to the south, leaning on a large boulder as to create an unmistakable shape of a giant erected phallos (fig. 2). The shape of the stone itself contributed to the vulgar impression, and the location of the monument just next to the main road probably made many travelers both laugh and gasp. Archaeologically, the stone would normally be interpreted as an Iron Age burial monument (c. 500 BC - AD 1050). Early depictions, however, indicate that the stone is in fact part of a larger monument, i.e. the stern stone of a large ship-shaped stone setting, typically from the Bronze age or the Iron Age (PAPMEHL-DUFAY e GOLDHAHN, 2018: 13ff) (fig. 3). In fact, one of the elderly people in the village gave an account of how he, as a 7-year old child in the late 1930s, witnessed the removal by farmers of the ship's northern stern stone (PAPMEHL-DUFAY e GOLDHAHN, 2018: 51).

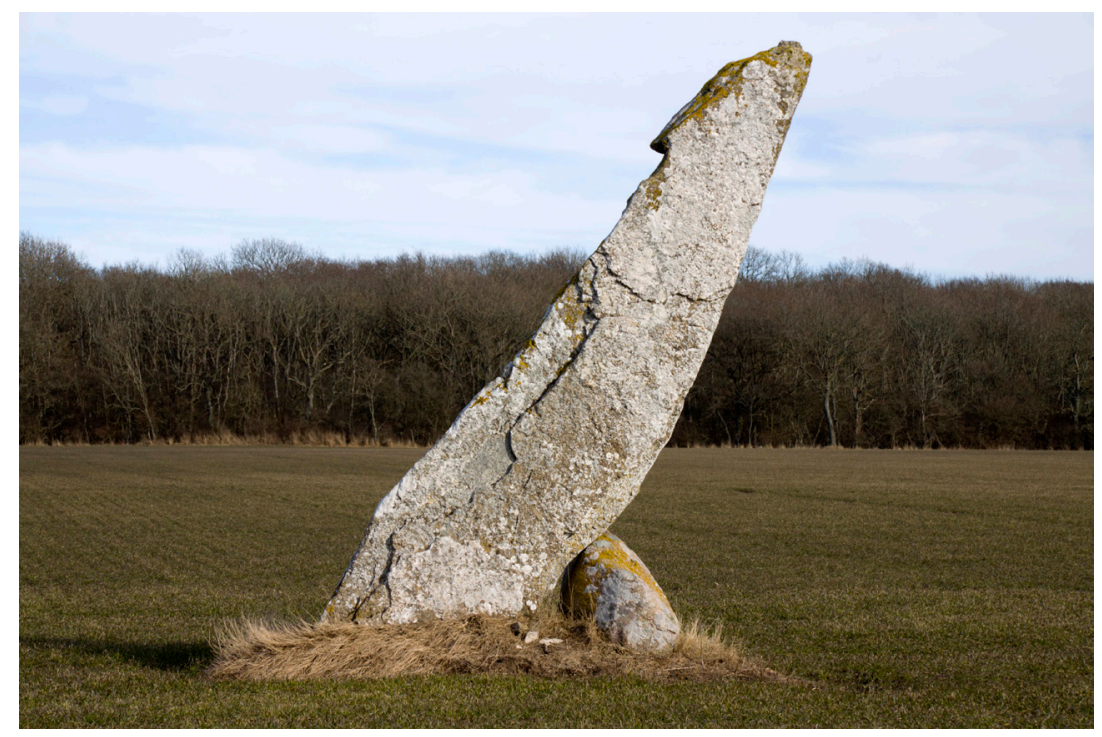

Figure 2. The $4 \mathrm{~m}$ tall Albrunna stone, as it appeared in 2013. Photo by Staffan Lagerström. 


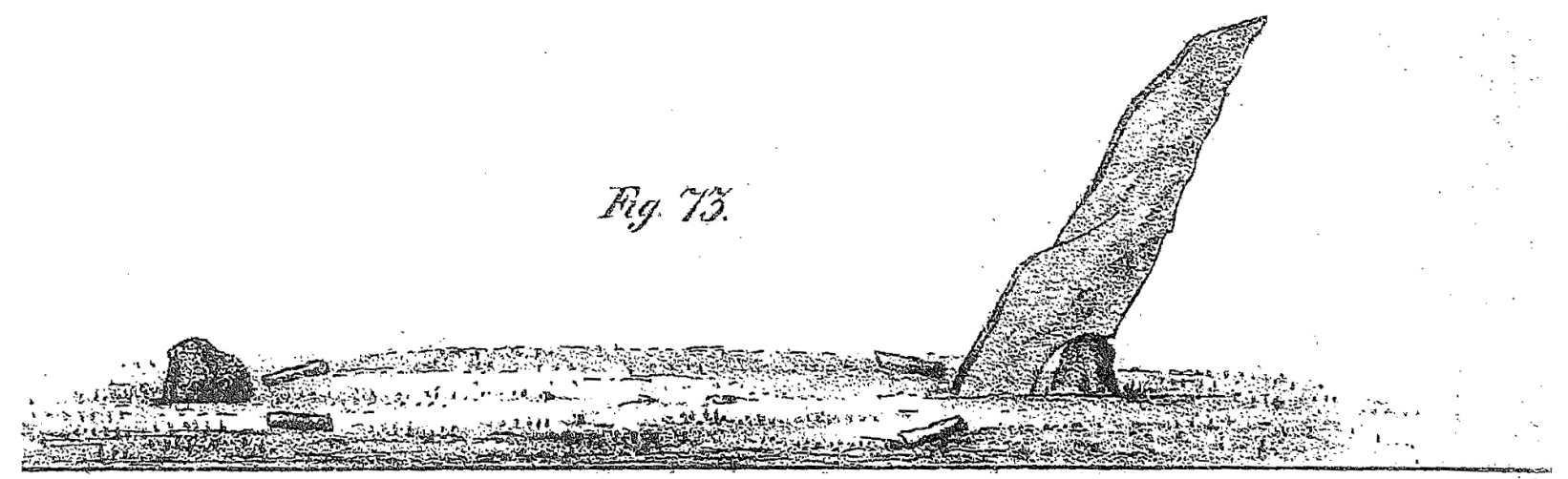

Figure 3. Drawing of the Albrunna monument from 1822, showing the stone as the southern part of a large shipshaped monument. After Sjöborg 1830.

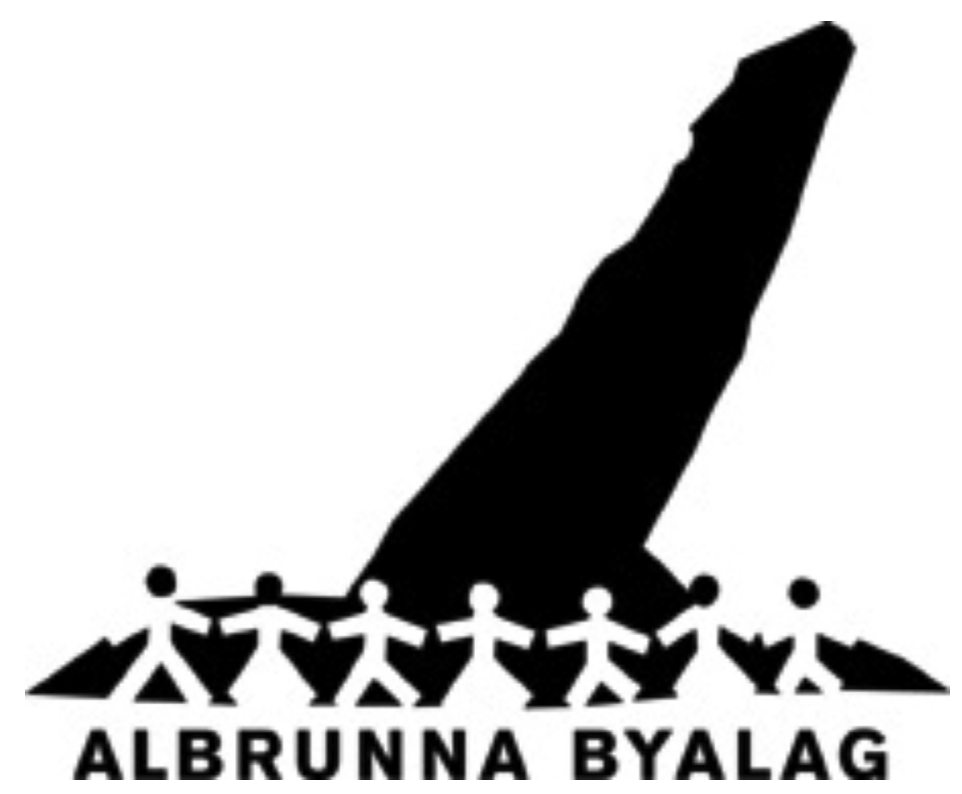

Figure 4. Logotype for the village community of Albrunna. Courtsey of Ann-Sofi Wase Vestberg, Albrunna.

Stone ship or not, the giant phallos of Albrunna has come to function as a major local landmark, and its silhouette was even used as a graphic symbol for the local village community (fig. 4). Clearly, its peculiar shape rendered the small village some form of fame, with innumerable pictures taken of the stone with people posing in various ways in connection to it. The Albrunna stone played an important role in local place attachment and in creating a sense of common identity for the local community, thus its significance locally adheres to the above-mentioned social value of heritage (JONES, 2017). It was then no less than a small disaster when, in the fall of 2014, the Albrunna stone accidently fell over and broke into pieces (fig. 5). 


\section{Fornminne föll vid plöjning}

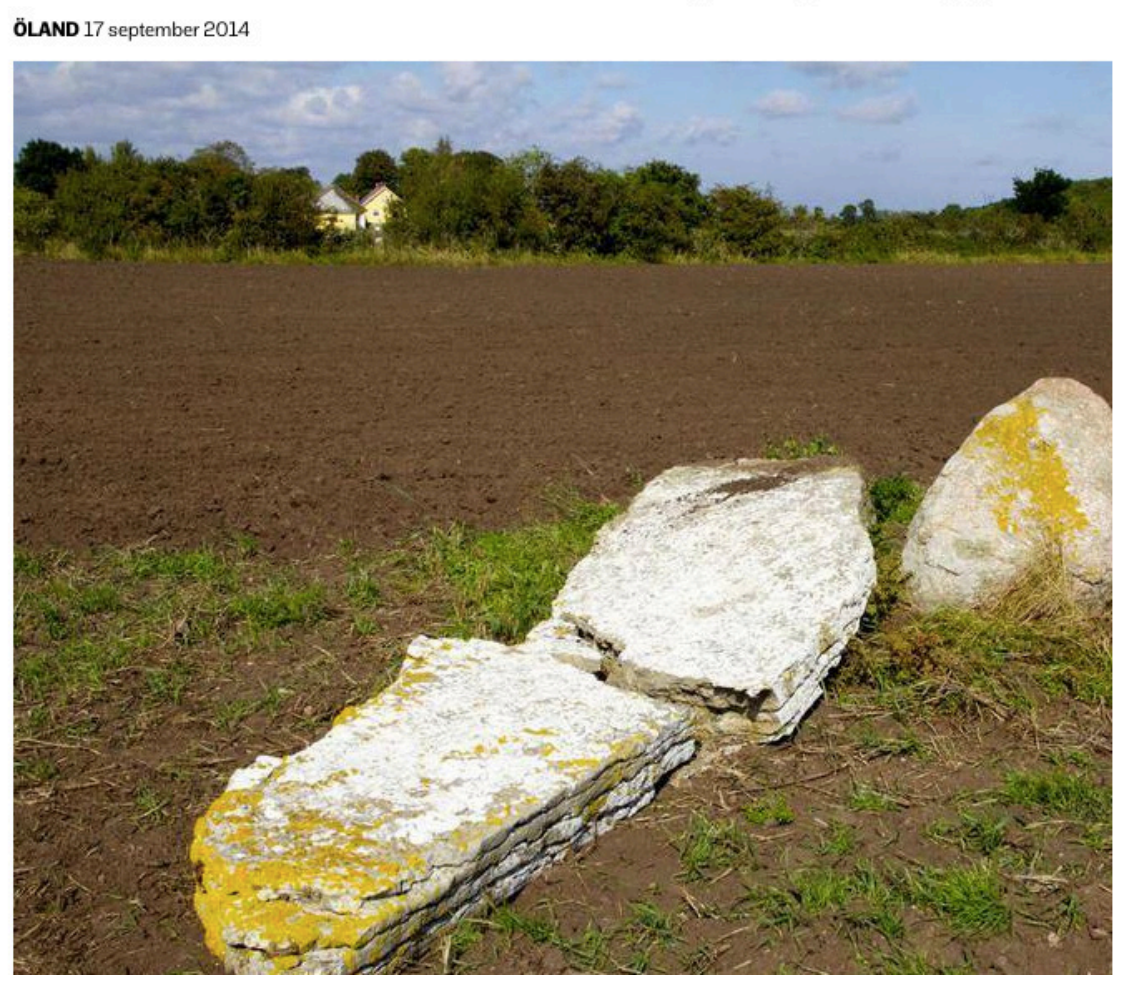

Figure 5. The news of the shattered Albrunna stone hit Öland in the autumn of 2014. From the local newspaper Barometern, Sept. $17^{\text {th }}, 2014$.

The accident evoked strong emotions locally, resulting in numerous phone calls to the regional antiquarian authorities demanding the stone to be repaired and re-erected. The immediate response was "yes", but it soon turned out more difficult than first envisioned due to the poor condition of the remaining fragments. Thus, the sad remnants of the once proud monument were left lying as they fell for almost two years, leaving a flat and empty space. Local voices however were not happy with this, and the authorities were repeatedly and intensively urged to make the stone standing again. "We felt that we've been deprived of something", one of the villagers later explained. Apparently, the ancient vulgar silhouette had become an important part of the local identity and when it fell, the village not only lost its "skyline" but a part of its identity. A wound was cut opened in the local community, that seemingly could only be healed if the stone was re-erected.

Expertise was consulted as to the possibilities of mending the broken pieces, but it was again confirmed that this was not possible. Various potential solutions were suggested, and after a dialogue with the local community the authorities decided in May 2016 to commission a concrete copy of the original stone to be produced and erected at the original spot. Hence, the remnants of the original stone were transported to a nearby storage room where stone conservators spent the winter 2016-2017 producing as exact a copy as possible. 


\section{FROM STONE TO SHIP}

Before the copy of the Albrunna stone could be erected, an excavation of the original remains was needed. This was conducted by Linnaeus University archaeology students under my supervision during two weeks in September 2016. A full account of the excavation is available in Swedish (PAPMEHL-DUFAY e GOLDHAHN, 2018).

Initially, the area surrounding the remains of the stone itself was investigated and it was confirmed that the characteristic tilting of the stone in fact was intentional, i.e. it had been placed in a tilting position when it was erected. Thus, the phallic shape most likely was not a chance but an intended expression of the monument by its builders. Just north of the erected stone, oblique marks could be seen from removed stone slabs possibly indicating the rails of a ship-shape extending to the north. Therefore, the second week of the excavation was spent on removing the topsoil and investigating the area to the north of the Albrunna stone. Here, clear traces of a ship-shaped stone setting appeared, c. $26 \mathrm{~m}$ in length in total, with the tall phallic Albrunna stone having marked the southern stern (fig. 6). The marks of the rail-stones were clearly visible, and in the northern part several rail-stones were still partly present. The foundation pit for the northern stern stone was filled with limestone fragments, probably a result of it having been blown into pieces in the 1930s. The elderly man in the village, who told us of how he as a child witnessed the removal of the northern stone, accompanied us during the removal of the top soil. He was delighted when we could confirm that there in fact had been a northern stone. That it seemed to have been blown to pieces, and not removed by horse-power as he recalled, did not seem to bother him.

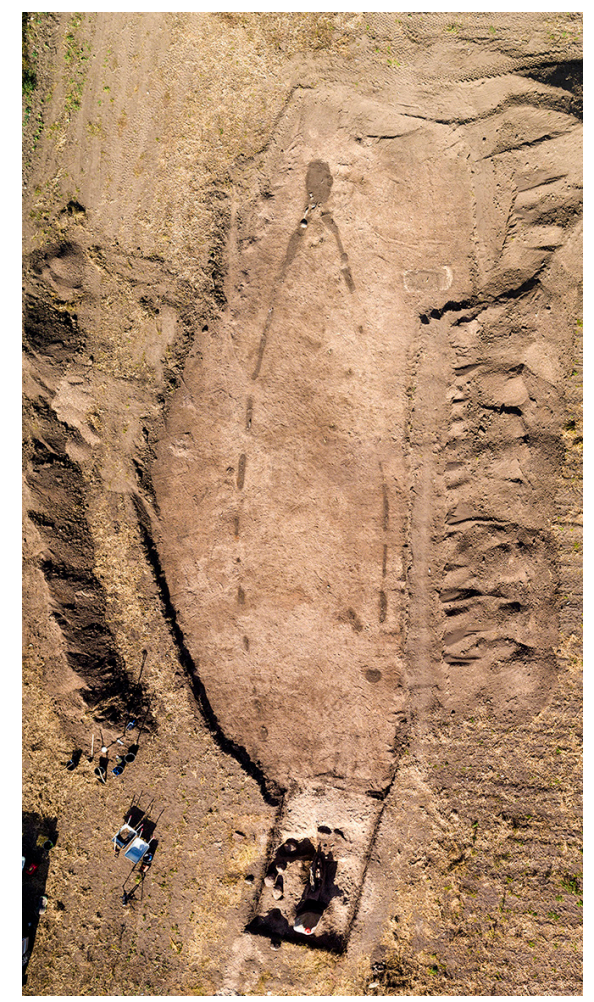

Figure 6. The contours of the stone ship as it appeared after the top soil had been removed. The remains of the Albrunna stone are in the lowermost part of the picture. Photo by Sebastian Jakobsson. 


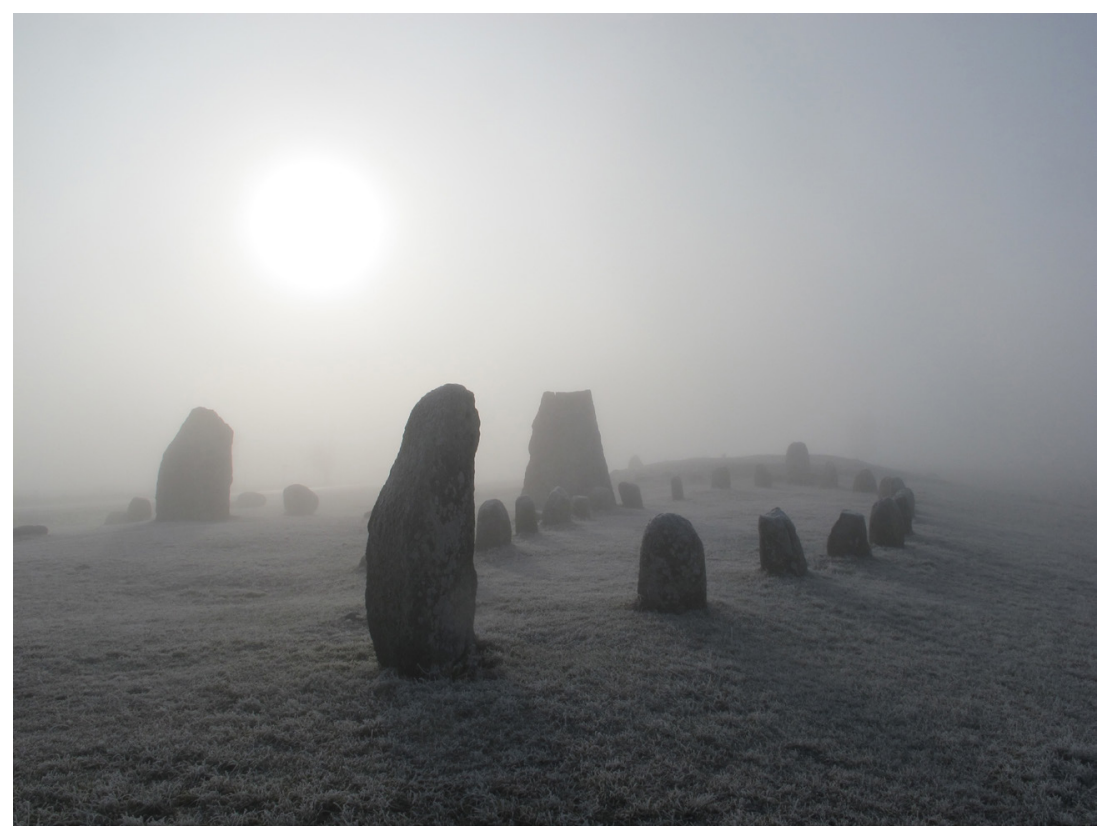

Figure 7. Ship-shaped stone setting at Gettlinge, SW Öland, about 8 km to the north of Albrunna. Photo by the author.

In this way, the brief but intensive archaeological excavation turned the Albrunna stone into the Albrunna ship, placing it alongside about 40 known monuments of this type on the island (fig. 7) (PAPMEHL-DUFAY e GOLDHAHN, 2018: 69ff). Ship-shaped stone settings in Scandinavia typically date to either the Bronze Age (c. 1700-500 BC) or the late Iron Age (around AD 500-1000) (SKOGLUND 2008; WEHLIN, 2013). They range in size from just a couple of meters up to c. $50 \mathrm{~m}$ or more in length (ARTELIUS et al. 1994:19ff). The longest known stone ship in Sweden is Ales stenar in Askeberga, Skåne, measuring $67 \mathrm{~m}$ in length (ANDERSSON et al., 2013). In Jelling, Denmark, a stone ship c. 170 $m$ in length has been recorded, by far the largest ever known (RANDSBORG, 2008). The stone ships sometimes contain the cremated remains of one or more individuals, but in other cases no such remains are found and their presence at cemeteries could also be understood in terms of their inherent symbolism expressing themes connected to journeys, travelling and reproduction.

Throughout much of Scandinavian prehistory, the ship has been a central symbol used in various context and different materials, denoting a range of aspects related to life and death such as travelling, knowledge, fertility and prosperity (KOBYLINSKI e RABIEGA, 2018). The fertility aspects are particularly interesting in relation to the Albrunna ship, given the massive phallos-shaped southern stern that in combination with the ship-shape itself would have presented the monument with powerful symbolic associations to male as well as female fertility and reproduction.

The date of the Albrunna ship is still not entirely settled. During the excavation, prehistoric finds were limited to a few pieces of cremated bone spread out along the ship's rail and some unburnt animal bone fragments found close to the southern stern stone. The disappointing lack of prehistoric finds was compensated, however, by a highly interesting object that was recovered just next to the remains of the standing stone itself. Here, a plastic bag containing a small glass jar was found. Inside the jar was a letter, written by a young couple addressing themselves in the future. The letter was dated to May $22^{\text {nd }}$ 2012. On one side, it had the following text (translated from Swedish): 
Now it is:

Simon only wants to sleep on Stinas arm

We fight a lot because we can't really reach each other + an eternal tiredness Stina has a hard time with Alva and Jonathan

Daniel has crazy emotional outbreaks

We have decided to take our future seriously

Daniel is super-tired of his job as a teacher

Our flat feels overcrowded

On the other side, it said:

What has happened when we read this? Are we both alive?

Are we still a couple?

Has Simon got a "sibling"?

Have we moved?

Did Daniel manage his education? Has Stina finished her education? Has Stina got a job?

Does the domestic situation work better? What are we longing for now?

Have we been on any "travel"? Bus Are our near and dear alive?

Are we healthy?

Have we won the lottery?

Although clearly modern and not archaeological at all in the traditional sense, this no doubt was the most interesting and revealing find of the Albrunna excavation. In a time of hardship, two young parents have turned to a relic of the past to communicate with their future. The jar used as a container for their message was not just any jar, but a baby food jar. And the monument they chose was not just any relic, but one explicitly expressing aspects of reproduction and fertility. In fact, this find is to a high degree archaeological: it was buried in the ground, intentionally, at a carefully selected location, with a clear reference to the past as well as to the future. It also contains a message that we can understand, and it provides us with a number of clues as to the significance of the location chosen and the mindset and the hardships of the people involved in its deposition. In essence, it manifests the significance of the Albrunna monument in the present and the power of using the past to manage the future. 


\section{RE-ERECTING THE ALBRUNNA STONE}

Shortly after the excavation at Albrunna was finished, the efforts of creating a concrete copy of the stone started. For several months, two stone conservators were occupied with taking a silicon cast of the original fragments and using it to cast a $6 \mathrm{~m}$ long concrete replica (including the part that was to be underground) to be erected at the site. The cast was made one-sided, so that the side of the slab facing the road would have the exact surface structure of the original, while the side of the slab facing away from the road would be flat. Here, a small metal plaque was inserted, informing the visitor about the monument being a replica as well as a brief account of its production. A large pit was dug at the site of the original stone, leaving the boulder in place on which it has been leaning. The concrete copy was put in place and secured by filling the pit with concrete. On May $12^{\text {th }} 2017$, the new Albrunna stone was solemnly uncovered in front of a cheering crowd of local inhabitants and representatives of authorities, archaeologists and local media (fig. 8). All seemed happy with the giant phallos being back in place, order restored. The original fragments were later placed on an adjacent parking lot accompanied by a signpost presenting the history of the monument, including the results from the excavation and the reasons for its reconstruction (fig. 9).

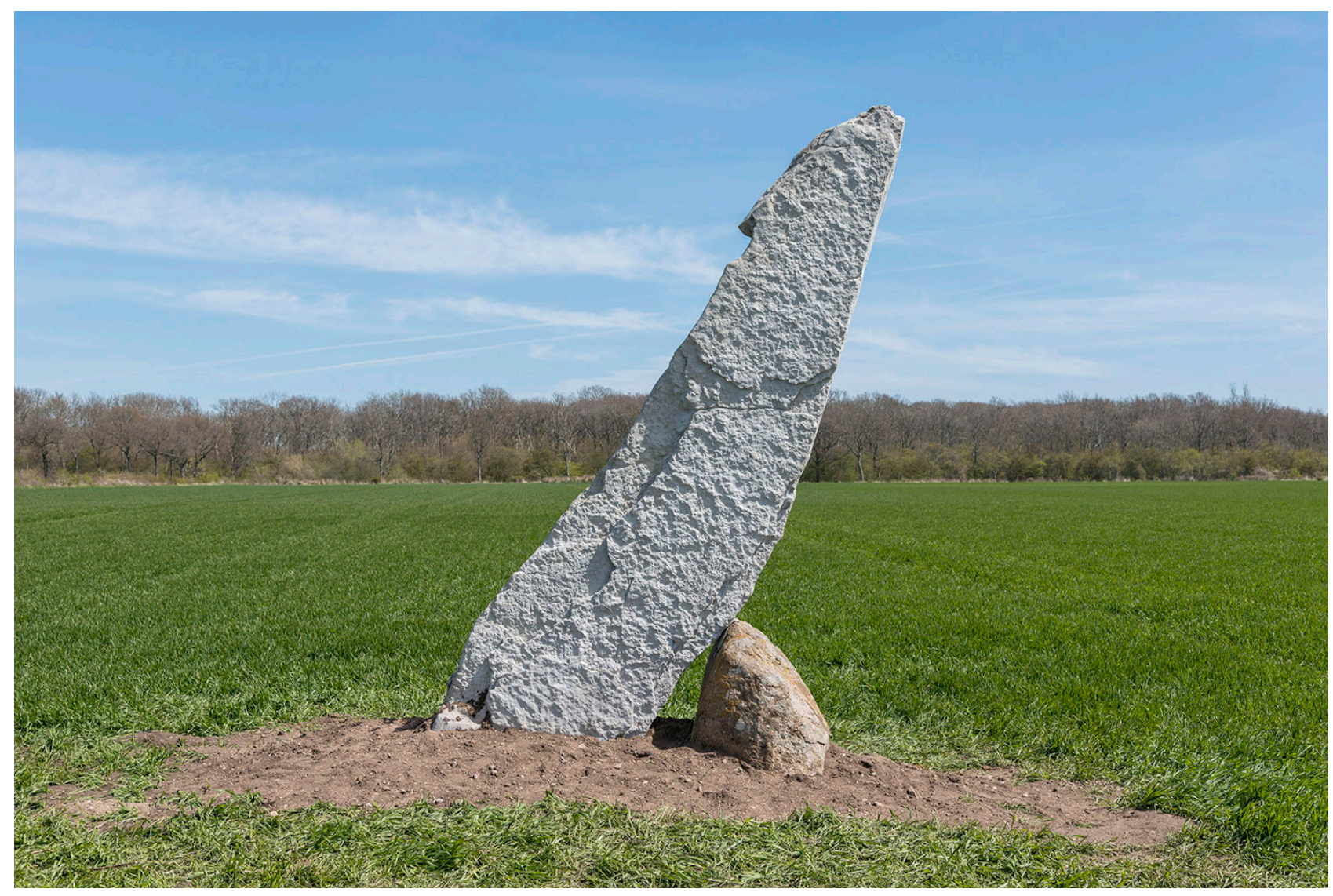

Figure 8. The newly uncovered Albrunna concrete stone, May 2017. Photo by the author. 

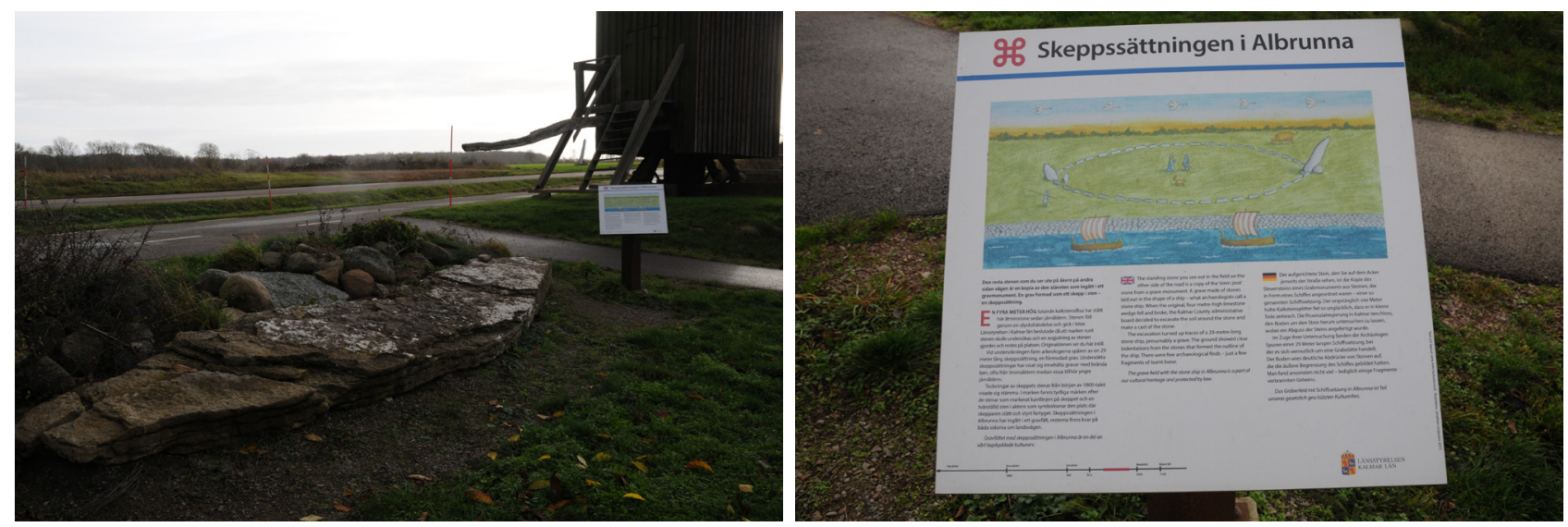

Figure 9. Display of the shattered original, together with a signpost, at the adjacent parking lot. The concrete copy is visible in the background. Photo by the author.

A couple of years later, I interviewed some of the villagers asking them what they felt about this whole affair. While the concrete copy was clearly appreciated and regarded "the best we could get", not all of the informants were altogether happy with it. While the shape and the surface structure of the copy indeed resemble the original in detail, its material and color does not and the general impression is that it looks new, homogeneously grey and lacking the patina of the withered original. It seems something of the age value of the monument was lost in the process. "When the Yellow Wagtail rests upon it, it feels OK, but otherwise is just stands there, lifeless", one of the informants explained. The term "lifeless" is interesting in this context; apparently, this informant experienced that the original stone had a quality of life, while the copy didn't. But when the familiar bird rested on the copy like it used to do on the original, something of this life was temporarily brought back. Hence, the sense of aura rested not only in the original stone itself but in the perception of its setting, the physical environment surrounding it and even a bird commonly seen resting on it. This connects to Holtorf's concept of "Pastness", which is something that can be reproduced if we only know what buttons to push (HOLTORF, 2017). I guess none of us would have thought of the bird, though.

The view that the concrete copy lacks the glory of its predecessor apparently was shared by several in the community, and while the whole affair of getting the stone back had created a strong community engagement, now that the concrete copy was in place the local interest in the Albrunna stone had diminished. The skyline is back, but there is still something missing.

\section{COMMUNITY ENGAGEMENT IN A SMALL RURAL SETTING}

The fall of the Albrunna stone initiated a community-based endeavor that resulted in new archaeological knowledge as well as the reconstruction of a massive ancient monument. In this sense, it could be seen as a successful community archaeology project. It differs from the general view on community archaeology, however, in that the archaeologist were not present initially and 
that the excavation and production of archaeological knowledge were not part of the goals originally set up (e.g. MOSER et al., 2002; TULLY, 2007; see also MARSHALL, 2012). The initiative originated from the local residents themselves, whose involvement focused on re-erecting the stone and was directed specifically towards the regional antiquarian authorities. A dialogue between the authorities and the local community resulted in the slightly unusual decision by the authorities to spend a considerable amount of tax-payers money on creating a giant concrete phallos and erecting it on a field just next to the main road on the idyllic Öland countryside. The setup of the archaeological excavation project was not formulated with an explicit community archaeological agenda in mind, but merely as a commissioned investigation of the remnants of a damaged monument in order to facilitate its reconstruction (PAPMEHL-DUFAY e GOLDHAHN, 2018). Once the excavation happened, however, the local engagement was strong and extremely positive. From the archaeologist's point of view, this was met with enthusiasm and resulted in numerous tours of the site as well as a $30 \mathrm{~min}$ documentary (available at https://youtu.be/FBDS4aNLaUo). Still, despite some rather substantial new archaeological evidence being uncovered, turning the "Albrunna stone" into the "Albrunna ship", the view of the monument in the local community apparently did not change much at least not in this sense. What we see is a disconnection between scientific knowledge and public heritage value, where the latter seems more or less independent in relation to the former. Even from the authorities, the new archaeological evidence did not affect the overall "story" of the site to any great extent, and the reconstruction still dealt only with the phallic stone representing the southern stern of the ship and not the ship itself.

\section{CONCLUDING REFLECTIONS}

The Albrunna case highlights some interesting points related to heritage management, heritage values and the significance of archaeological heritage from different perspectives. At first glance, the challenge in this case was quite straight-forward: the local community lost their beloved vulgar silhouette, and wanted it back. Authorities wanted to make the community happy, so they produced as exact a copy as they could and put it back. Still, the aura of the Albrunna stone is not wat it used to be. Could this have been done differently?

I think one key point is the disconnection between the official appreciation and assessment of values on the one hand, and the significance of the monument for the local community on the other. The regional antiquarian authorities quite naturally focused on the shape of the stone and the silhouette of the finished reconstruction. In the dialogue with the villagers, this was what was expressed as important to retrieve. But at the heart of the stone's value for the local community lay something else, not easily expressed and apparently not captured by the replica. One of the informants talked about the "lifelessness" of the replica, hinting on the complexity of getting this right. From my point of view, this relates to the "pastness" of the monument, which included not only the physical appearance of the stone itself, but the perception of it by the individual villagers themselves and even activities performed around it. The bird resting on the stone is part of this 
more complex web of significance: it represented the familiarity and the perception of the stone as it used to be, and as such had the ability of restoring something of the value of the original and temporarily pass it on to the replica.

The letter found during the excavation demonstrates the power of a monument like this in evoking feelings related to existence, the past and the future, but it is also a material testimony to the pastness of the monument itself. It was written at a time of hardship, expressing expectations and hope as well as fear for what the future may hold, and it was buried at a monument strongly associated with fertility, reproduction and the past. Importantly, it was buried with the intention of being recovered again at some point in the future. Here, the excavation unintendedly interrupted the anticipated course of events, and the letter is now kept in the regional museum storage. If instead the letter was reburied in connection to the replica, would something of the monument's pastness have been restored? Like the bird resting on the stone, but perceived perhaps only on a more metaphysical level?

As an archaeologist, I was thrilled to be able to demonstrate the full extent and character of the original monument, turning it from a single standing stone to a massive ship-shaped stone setting. My enthusiasm was no doubt shared by participating students as well as interested villagers, but to my surprise, the new evidence did not seem to affect in any significant way the meaning of the monument at large. My suggestion to reconstruct the whole ship was met with abidance, and while most people in the community now know that the stone originally was part of a ship-shaped monument, it's still called the "Albrunna stone" and not the "Albrunna ship". My reflection on this is that, although the excavation brought new knowledge about the site and the monument, it did not alter the existing narrative in any substantial way.

To conclude, the social value of ancient monuments rests in their pastness, and even though this at least partly can be recreated, its dimensions are multifold. Since reconstructions always contain aspects of interpretation, replicas will have a hard time fulfilling the same social and cultural space as original ancient monuments, at least from a local community perspective.

\section{ACKNOWLEDGEMENTS}

I am grateful to the people of Albrunna for their engagement and enthusiasm in connection to the Albrunna stone. Thanks also to the anonymous reviewers for their valuable suggestions. 


\section{REFERENCES}

ANDERSSON, M., KNARRSTRÖM, A., SÖDERBERG, B. e WALLEBOM, B. Ales stenar i nytt Ijus. UV Rapport 2013:80. Lund: Arkeologiska uppdragsverksamheten UV Syd, Riksantikvarieämbetet. 2013.

AUSTRALIA ICOMOS Practice note: Understanding and assessing cultural significance.

BENJAMIN, W. The Work of Art in the Age of Mechanical Reproduction. In: Illuminations, 217-51. New York: Schocken Books. (1936) 1968.

DUVAL, M., SMITH, B., GAUCHON, C., MAYER, L. e MALGAT, C. "I have visited the Chauvet Cave": the heritage experience of a rock art replica. International Journal of Heritage Studies 26(2):142-162. 2020.

HÄGGSTRÖM, L. Att definiera det perifera. Tidskrift. Arkeologi i sydöstra Sverige 3:7-19. 2003.

HÖGBERG, A., HOLTORF, C., MAY, S. e WOLLENTZ, G. No future in archaeological heritage management? World Archaeology 49(2):1-9. 2018.

HOLTORF, C. e SCHADLA-HALL, T. Age as artefact: On archaeological authenticity. European Journal of Archaeology 2(2):229-247. 1999.

HOLTORF, C. Perceiving the past: from age value to pastness. International Journal of Cultural Property 24:497-515. 2017.

JEFFREY, S. Challenging Heritage Visualisation: Beauty, Aura and Democratisation. Open Archaeology 1: 144-152. 2015.

JONES, S. Wrestling with the Social Value of Heritage: Problems, dilemmas and opportunities. Journal of Community Archaeology \& Heritage 4(1):21-37. 2017.

KOBYLINSKI, Z. e RABIEGA, K. The symbolic role of boats and ships in pagan and Christian Medieval Northern Europe. In: NEBELSICK, L. D., WAWRZENIUK, J. e ZEMAN-WISNIEWSKA, K. (eds.) Sacred space: contributions to the archaeology of belief. Archaeologica Hereditas. Warsaw: Institute of Archaeology of the Cardinal Stefan Wyszyński. 2018.

MARSHALL, Y. What is community archaeology? World Archaeology 34(2):211-219. 2012.

MOSER, S., GLAZIER, D., PHILLIPS, J. E., NASSER EL NEMR, L., SALEH MOUSA, M., NASR AIESH, R., RICHARDSON, S., CONNER, A. e SEYMOUR, M. Transforming archaeology through practice: strategies for collaborative archaeology and the Community Archaeology Project at Quseir, Egypt. World Archaeology 34:2, pp. 220-248. 2002.

MYDLAND, L. e GRAHN, W. Identifying heritage values in local communities. International Journal of Heritage Studies 18(6):564-587. 2012.

PAPMEHL-DUFAY, L. Shaping an identity. Pitted Ware pottery and potters in southeast Sweden. Theses and Papers in Scientific Archaeology 7. Stockholm: Stockholm university. 2006.

PAPMEHL-DUFAY, L. e GOLDHAHN, J. (eds.) Albrunnaskeppet -arkeologisk undersökning September 2016. Kalmar Studies in Archaeology XIV. Kalmar: Linnaeus University. 2018.

RANDSBORG, K. King's Jelling. Gorm e Thyra's palace, Haralds monument \& grave - Svend's cathedral. Acta Archaeologica 79, pp. 1-23. 2008. 
RIEGL, A. The Modern Cult of Monuments: Its Character and Its Origin. Oppositions 25, 21-51. 1982 (1903).

SFS 1988:950. Kulturmiljölag (1988:950). Statens författningssamling.

SJÖBORG, N. H. Samlingar för Nordens fornälskare. Tredje Tomen. Med 60 planscher. Stockholm. 1830.

SKOGLUND, P. Stone ships: continuity and change in Scandinavian prehistory. World Archaeology, 40:3, 390-406. 2008.

TULLY, G. Community archaeology: general methods and standards of practice. Public Archaeology 6:3, 155-187. 2007.

WEHLIN, J. 2013. Östersjöns skeppssättningar. Monument och mötesplatser under yngre bronsålder. GOTARC Serie B. Gothenburg Archaeological Theses 59. Göteborg. 2013. 